\title{
System Study: Emergency Power System 1998-2014
}

\author{
John A. Schroeder
}

December 2015

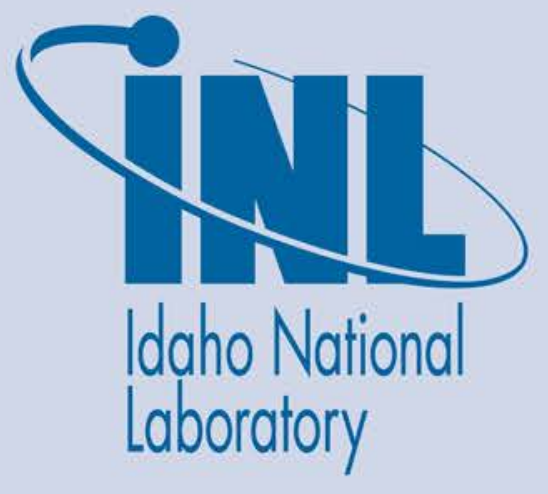

The INL is a U.S. Department of Energy National Laboratory operated by Battelle Energy Alliance 
NOTICE

This information was prepared as an account of work sponsored by an agency of the U.S. Government. Neither the U.S. Government nor any agency thereof, nor any of their employees, makes any warranty, express or implied, or assumes any legal liability or responsibility for any third party's use, or the results of such use, of any information, apparatus, product, or process disclosed herein, or represents that its use by such third party would not infringe privately owned rights. The views expressed herein are not necessarily those of the U.S. Nuclear Regulatory Commission. 


\title{
System Study: Emergency Power System 1998-2014
}

\author{
John A. Schroeder
}

Update Completed December 2015

\author{
Idaho National Laboratory \\ Risk Assessment and Management Services Department \\ Idaho Falls, Idaho 83415 \\ http://www.inl.gov
}

Prepared for the Division of Risk Assessment Office of Nuclear Regulatory Research

U.S. Nuclear Regulatory Commission

NRC Agreement Number NRC-HQ-14-D-0018 



\begin{abstract}
This report presents an unreliability evaluation of the emergency power system (EPS) at 104 U.S. commercial nuclear power plants. Demand, run hours, and failure data from fiscal year 1998 through 2014 for selected components were obtained from the Institute of Nuclear Power Operations (INPO) Consolidated Events Database (ICES). The unreliability results are trended for the most recent 10-year period while yearly estimates for system unreliability are provided for the entire active period. An extremely statistically significant increasing trend was observed for EPS system unreliability for an 8-hour mission. A statistically significant increasing trend was observed for EPS system start-only unreliability.
\end{abstract}


System Study

Emergency Power System
2014 Update December 2015 


\section{CONTENTS}

ABSTRACT .iii

ACRONYMS vii

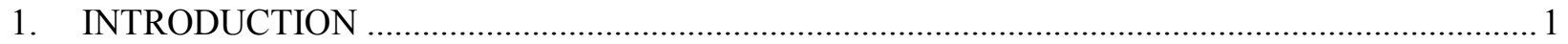

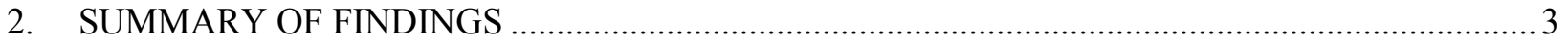

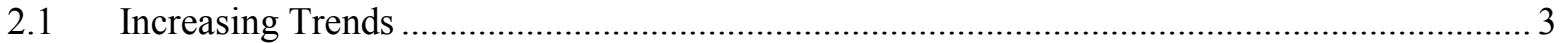

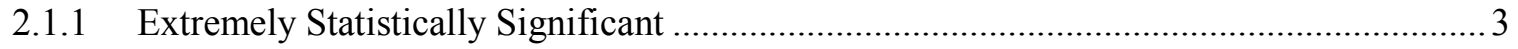

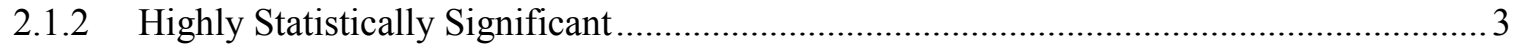

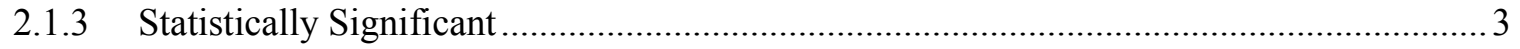

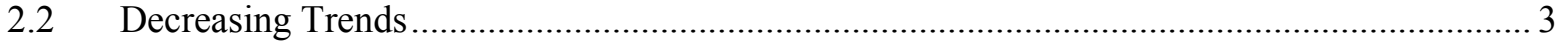

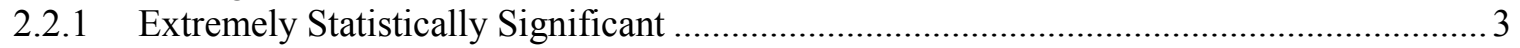

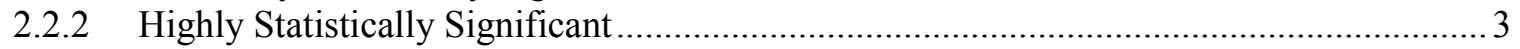

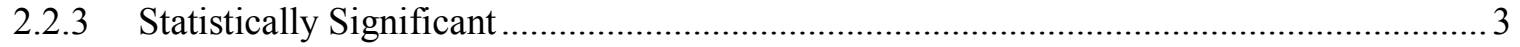

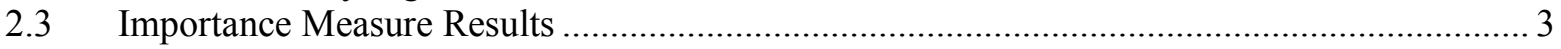

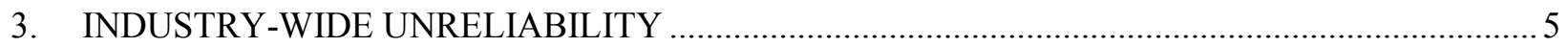

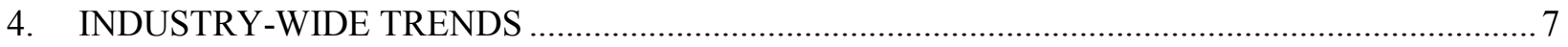

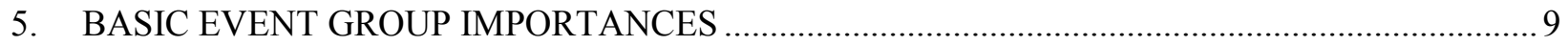

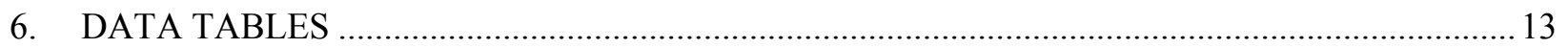

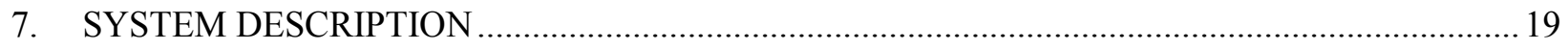

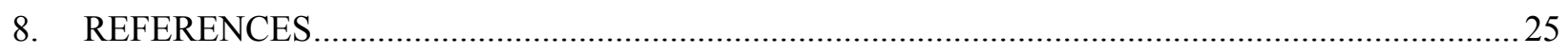

FIGURES

1. EPS start-only mission unreliability for Class 2,3 , and 4 and industry-wide groupings...................... 6

2. EPS 8-hour mission unreliability for Class 2, 3, and 4 and industry-wide groupings. ....................... 6

3. Trend of EPS system unreliability (start-only model), as a function of fiscal year............................ 8

4. Trend of EPS system unreliability (8-hour model), as a function of fiscal year................................. 8

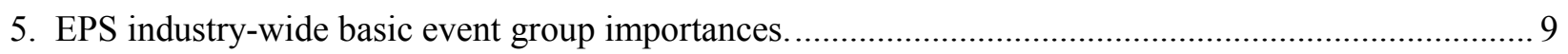

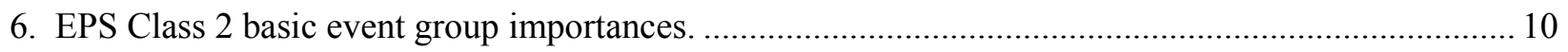




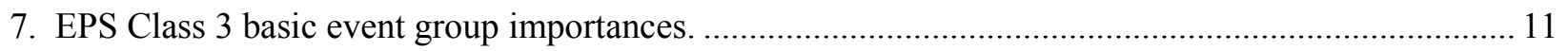

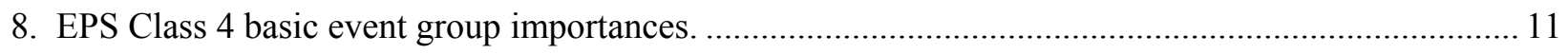

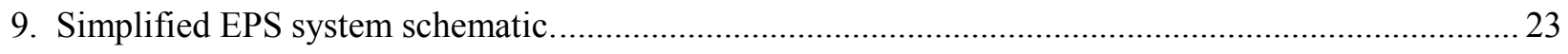

\section{TABLES}

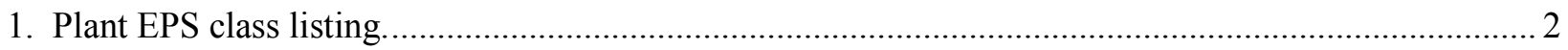

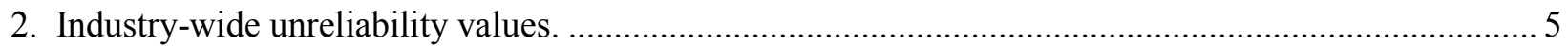

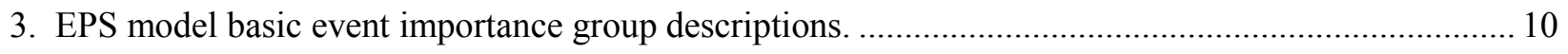

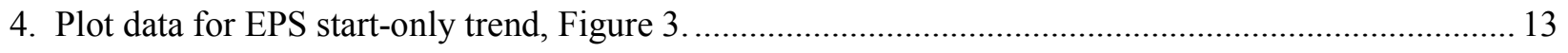

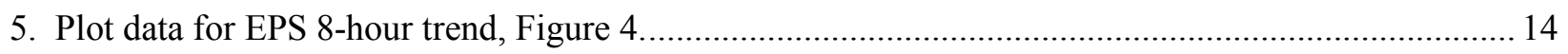

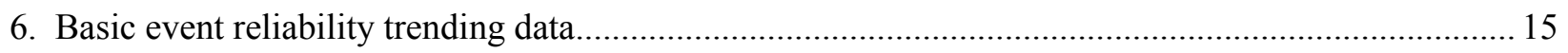

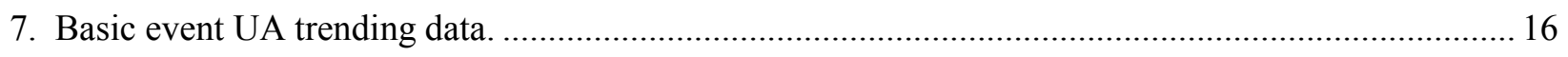

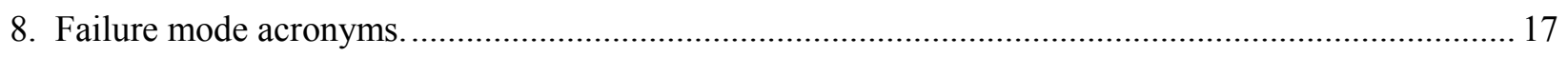

9. EPS configurations at U.S. commercial nuclear power plants.................................................. 20 


\title{
ACRONYMS
}

\author{
BWR boiling water reactor \\ CCF common-cause failure \\ EDG emergency diesel generator \\ EPIX Equipment Performance and Information Exchange \\ EPS emergency power system \\ FTLR fail to load/run \\ FTOC fail to open/close \\ FTOP fail to operate \\ FTR fail to run \\ FTR $<1 \mathrm{H}$ fail to run less than one hour (after start) \\ FTS fail to start \\ FY fiscal year \\ GTG gas turbine generator \\ HPCI high-pressure coolant injection \\ HTG hydro turbine generator \\ ICES INPO Consolidated Events Database \\ INPO Institute of Nuclear Power Operations \\ LOOP loss-of-offsite power \\ MSPI Mitigating Systems Performance Index \\ PRA probabilistic risk assessment \\ SO spurious operation \\ SPAR standardized plant analysis risk \\ SSU safety system unavailability \\ UA unavailability (maintenance or state of another component)
}


System Study

Emergency Power System
2014 Update December 2015 


\section{System Study: \\ Emergency Power System \\ 1998-2014}

\section{INTRODUCTION}

This report presents an unreliability evaluation of the emergency power system (EPS) at 104 U.S. commercial nuclear power plants listed in Table 1. For each plant, the corresponding Standardized Plant Analysis Risk (SPAR) model (version model indicated in Table 1) was used in the yearly calculations. Demand, run hours, and failure data from fiscal year (FY)-98 through FY-14 for selected components in the EPS were obtained from the Institute of Nuclear Power Operations (INPO) Consolidated Events Database (ICES). Train unavailability data (outages from test or maintenance) were obtained from the Reactor Oversight Process Safety System Unavailability (SSU) database (FY-98 through FY-01) and the Mitigating Systems Performance Index (MSPI) database (FY-02 through FY-14). Common-cause failure (CCF) data used in the models are from the 2010 update to the CCF database. The system unreliability results are trended for the most recent 10 -year period while yearly estimates for system unreliability are provided for the entire active period.

This report does not attempt to estimate basic event values for use in a probabilistic risk assessment (PRA). Suggested values for such use are presented in the 2010 Component Reliability Update (Reference 1), which is an update to Reference 2 (NUREG/CR-6928). Baseline EPS unreliability results using basic event values from that report are summarized in Section 3. Trend results for EPS (using system-specific data) are presented in Section 4. Similar to previous system study updates, Section 5 contains importance information (using the baseline results from Section 3), and Section 7 describes the EPS.

The EPS model is evaluated using the loss-of-offsite power (LOOP) flag set in the SPAR model. The LOOP flag set assumes all ac power is unavailable and that the EPS is required to perform to mitigate the effects of the LOOP initiating event. All models include failures due to unavailability while in test or maintenance. Human error has not been included in the SPAR model logic. An overview of the trending methods, glossary of terms, and abbreviations can be found in the Overview and Reference document on the Reactor Operational Experience Results and Databases web page.

Two modes of the models for the EPS are calculated. The EPS start-only model is the EPS SPAR model modified by setting all fail-to-run basic events to zero (False), setting unit cross-tie events to False, setting all recovery events to False, and setting all cooling basic events to False. The 8-hour mission model includes all basic events in the EPS SPAR model. 
Table 1. Plant EPS class listing.

\begin{tabular}{|c|c|c|c|c|c|c|c|c|}
\hline Class & Plant & Version & Class & Plant & Version & Class & Plant & Version \\
\hline Class 2 & Beaver Valley 1 & 8.22 & Class 2 & Vermont Yankee & 8.19 & Class 3 & San Onofre 3 & 8.22 \\
\hline Class 2 & Beaver Valley 2 & 8.23 & Class 2 & Waterford 3 & 8.16 & Class 3 & Sequoyah 1 & 8.16 \\
\hline Class 2 & Brunswick 1 & 8.2 & Class 2 & Wolf Creek & 8.2 & Class 3 & Sequoyah 2 & 8.16 \\
\hline Class 2 & Brunswick 2 & 8.2 & Class 3 & Arkansas 1 & 8.19 & Class 3 & South Texas 1 & 8.17 \\
\hline Class 2 & Callaway & 8.21 & Class 3 & Arkansas 2 & 8.21 & Class 3 & South Texas 2 & 8.17 \\
\hline Class 2 & Clinton 1 & 8.17 & Class 3 & Braidwood 1 & 8.21 & Class 3 & St. Lucie 1 & 8.19 \\
\hline Class 2 & Columbia 2 & 8.16 & Class 3 & Braidwood 2 & 8.21 & Class 3 & St. Lucie 2 & 8.19 \\
\hline Class 2 & Comanche Peak 1 & 8.21 & Class 3 & Byron 1 & 8.21 & Class 3 & Surry 1 & 8.19 \\
\hline Class 2 & Comanche Peak 2 & 8.21 & Class 3 & Byron 2 & 8.21 & Class 3 & Surry 2 & 8.15 \\
\hline Class 2 & Cook 1 & 8.2 & Class 3 & Calvert Cliffs 1 & 8.22 & Class 3 & Susquehanna 1 & 8.23 \\
\hline Class 2 & Cook 2 & 8.2 & Class 3 & Calvert Cliffs 2 & 8.21 & Class 3 & Susquehanna 2 & 8.21 \\
\hline Class 2 & Cooper & 8.22 & Class 3 & Catawba 1 & 8.2 & Class 3 & Three Mile Isl 1 & 8.2 \\
\hline Class 2 & Crystal River 3 & 8.16 & Class 3 & Catawba 2 & 8.2 & Class 3 & Turkey Point 3 & 8.2 \\
\hline Class 2 & Davis-Besse & 8.19 & Class 3 & Diablo Canyon 1 & 8.19 & Class 3 & Turkey Point 4 & 8.2 \\
\hline Class 2 & Duane Arnold & 8.22 & Class 3 & Diablo Canyon 2 & 8.19 & Class 3 & Vogtle 1 & 8.21 \\
\hline Class 2 & Fort Calhoun & 8.2 & Class 3 & Farley 1 & 8.18 & Class 3 & Vogtle 2 & 8.21 \\
\hline Class 2 & Ginna & 8.23 & Class 3 & Farley 2 & 8.18 & Class 3 & Watts Bar 1 & 8.16 \\
\hline Class 2 & Grand Gulf & 8.22 & Class 3 & Hatch 1 & 8.2 & Class 4 & Browns Ferry 1 & 8.22 \\
\hline Class 2 & Harris & 8.23 & Class 3 & Hatch 2 & 8.2 & Class 4 & Browns Ferry 2 & 8.22 \\
\hline Class 2 & Kewaunee & 8.2 & Class 3 & Hope Creek & 8.18 & Class 4 & Browns Ferry 3 & 8.18 \\
\hline Class 2 & McGuire 1 & 8.2 & Class 3 & Indian Point 2 & 8.19 & Class 4 & Dresden 2 & 8.18 \\
\hline Class 2 & McGuire 2 & 8.2 & Class 3 & Indian Point 3 & 8.2 & Class 4 & Dresden 3 & 8.18 \\
\hline Class 2 & Monticello & 8.2 & Class 3 & La Salle 1 & 8.21 & Class 4 & Fermi 2 & 8.2 \\
\hline Class 2 & Nine Mile Pt. 1 & 8.21 & Class 3 & La Salle 2 & 8.21 & Class 4 & FitzPatrick & 8.17 \\
\hline Class 2 & Nine Mile Pt. 2 & 8.17 & Class 3 & Millstone 2 & 8.17 & Class 4 & Limerick 1 & 8.2 \\
\hline Class 2 & Oconee 1 & 8.19 & Class 3 & Millstone 3 & 8.2 & Class 4 & Limerick 2 & 8.19 \\
\hline Class 2 & Oconee 2 & 8.19 & Class 3 & Palo Verde 1 & 8.2 & Class 4 & North Anna 1 & 8.2 \\
\hline Class 2 & Oconee 3 & 8.19 & Class 3 & Palo Verde 2 & 8.2 & Class 4 & North Anna 2 & 8.2 \\
\hline Class 2 & Oyster Creek & 8.22 & Class 3 & Palo Verde 3 & 8.2 & Class 4 & Point Beach 1 & 8.2 \\
\hline Class 2 & Palisades & 8.2 & Class 3 & Peach Bottom 2 & 8.25 & Class 4 & Point Beach 2 & 8.2 \\
\hline Class 2 & Perry & 8.19 & Class 3 & Peach Bottom 3 & 8.21 & Class 4 & Prairie Island 1 & 8.19 \\
\hline Class 2 & Pilgrim & 8.21 & Class 3 & River Bend & 8.2 & Class 4 & Prairie Island 2 & 8.19 \\
\hline Class 2 & Robinson 2 & 8.17 & Class 3 & Salem 1 & 8.2 & Class 4 & Quad Cities 1 & 8.18 \\
\hline Class 2 & Seabrook & 8.2 & Class 3 & Salem 2 & 8.2 & Class 4 & Quad Cities 2 & 8.18 \\
\hline Class 2 & Summer & 8.23 & Class 3 & San Onofre 2 & 8.22 & & & \\
\hline
\end{tabular}




\section{SUMMARY OF FINDINGS}

The results of this EPS system unreliability study are summarized in this section. Of particular interest is the existence of any statistically significant ${ }^{\mathrm{a}}$ increasing trends.

\subsection{Increasing Trends}

\subsubsection{Extremely Statistically Significant}

- EPS system unreliability for an 8-hour mission was found to be increasing.

\subsubsection{Highly Statistically Significant}

- None

\subsubsection{Statistically Significant}

- Start-only EPS system unreliability was found to be increasing.

\subsection{Decreasing Trends}

\subsubsection{Extremely Statistically Significant}

- None

\subsubsection{Highly Statistically Significant}

- None.

\subsubsection{Statistically Significant}

- None.

\subsection{Importance Measure Results}

The industry-wide EPS start-only and 8-hour basic event group importances were evaluated and are shown in Figure 5. In both cases, the leading contributors to EPS system unreliability are the $1 \mathrm{E}$ Generator group of basic events and AC Power. In addition, generator auxiliary equipment and the sequencer are important to the start-only model. In addition, cooling and human action are important for the 8-hour mission model.

a. Statistically significant is defined in terms of the 'p-value.' A p-value is a probability indicating whether to accept or reject the null hypothesis that there is no trend in the data. P-values of less than or equal to 0.05 indicate that we are $95 \%$ confident that there is a trend in the data (reject the null hypothesis of no trend.) By convention, we use the "Michelin Guide" scale: p-value $<0.05$ (statistically significant), p-value $<0.01$ (highly statistically significant); pvalue $<0.001$ (extremely statistically significant). 
System Study

Emergency Power System
2014 Update December 2015 


\section{INDUSTRY-WIDE UNRELIABILITY}

The EPS fault trees from the SPAR models were evaluated for each of the 104 operating U.S. commercial nuclear power plants.

The industry-wide unreliability of the EPS has been estimated for two modes of operation. A startonly model and an 8-hour mission model were evaluated, see Table 2. The uncertainty distributions for the EPS classes include both plant design variability (within a class) and parameter uncertainty while using industry-wide component failure data (FY-98 through FY-10). ${ }^{a}$ Table 2 shows the percentiles and mean of the aggregated sample data (Latin hypercube, 1000 samples for each model) collected from the uncertainty calculations of the EPS fault trees in the SPAR models. In Figure 1 and Figure 2, the 5th and 95th percentiles and mean point estimates are shown each class and for the industry.

In Figure 1 and Figure 2, the width of the distribution for a class is affected by the differences in the plant modeling and the parameter uncertainty used in the models. Because the width is affected by the plant modeling, the width is also affected by the number of different plant models in a class. For those classes with very few plants that share a design, the width can be very small.

Table 2. Industry-wide unreliability values.

\begin{tabular}{cccccc}
\hline Model & EPS Grouping & $\begin{array}{c}\text { Lower } \\
\mathbf{( 5 \% )}\end{array}$ & Median & Mean & $\begin{array}{c}\text { Upper } \\
\mathbf{( 9 5 \% )}\end{array}$ \\
\hline Start-Only & Industry & $2.45 \mathrm{E}-07$ & $3.98 \mathrm{E}-05$ & $1.92 \mathrm{E}-04$ & $5.45 \mathrm{E}-04$ \\
& Class 2 & $2.00 \mathrm{E}-06$ & $1.40 \mathrm{E}-04$ & $3.07 \mathrm{E}-04$ & $7.23 \mathrm{E}-04$ \\
& Class 3 & $1.29 \mathrm{E}-06$ & $2.57 \mathrm{E}-05$ & $1.56 \mathrm{E}-04$ & $4.76 \mathrm{E}-04$ \\
& Class 4 & $1.59 \mathrm{E}-08$ & $4.83 \mathrm{E}-06$ & $2.46 \mathrm{E}-05$ & $6.79 \mathrm{E}-05$ \\
& Industry & $6.37 \mathrm{E}-06$ & $2.25 \mathrm{E}-04$ & $9.07 \mathrm{E}-04$ & $2.54 \mathrm{E}-03$ \\
\hline \multirow{3}{*}{ 8-hour Mission } & Class 2 & $2.33 \mathrm{E}-05$ & $7.13 \mathrm{E}-04$ & $1.47 \mathrm{E}-03$ & $3.30 \mathrm{E}-03$ \\
& Class 3 & $1.69 \mathrm{E}-05$ & $2.24 \mathrm{E}-04$ & $7.33 \mathrm{E}-04$ & $2.05 \mathrm{E}-03$ \\
& Class 4 & $5.74 \mathrm{E}-07$ & $1.88 \mathrm{E}-05$ & $8.49 \mathrm{E}-05$ & $2.63 \mathrm{E}-04$ \\
\hline
\end{tabular}

a. By using industry-wide component failure data, individual plant performance is not included in the distribution of results. 


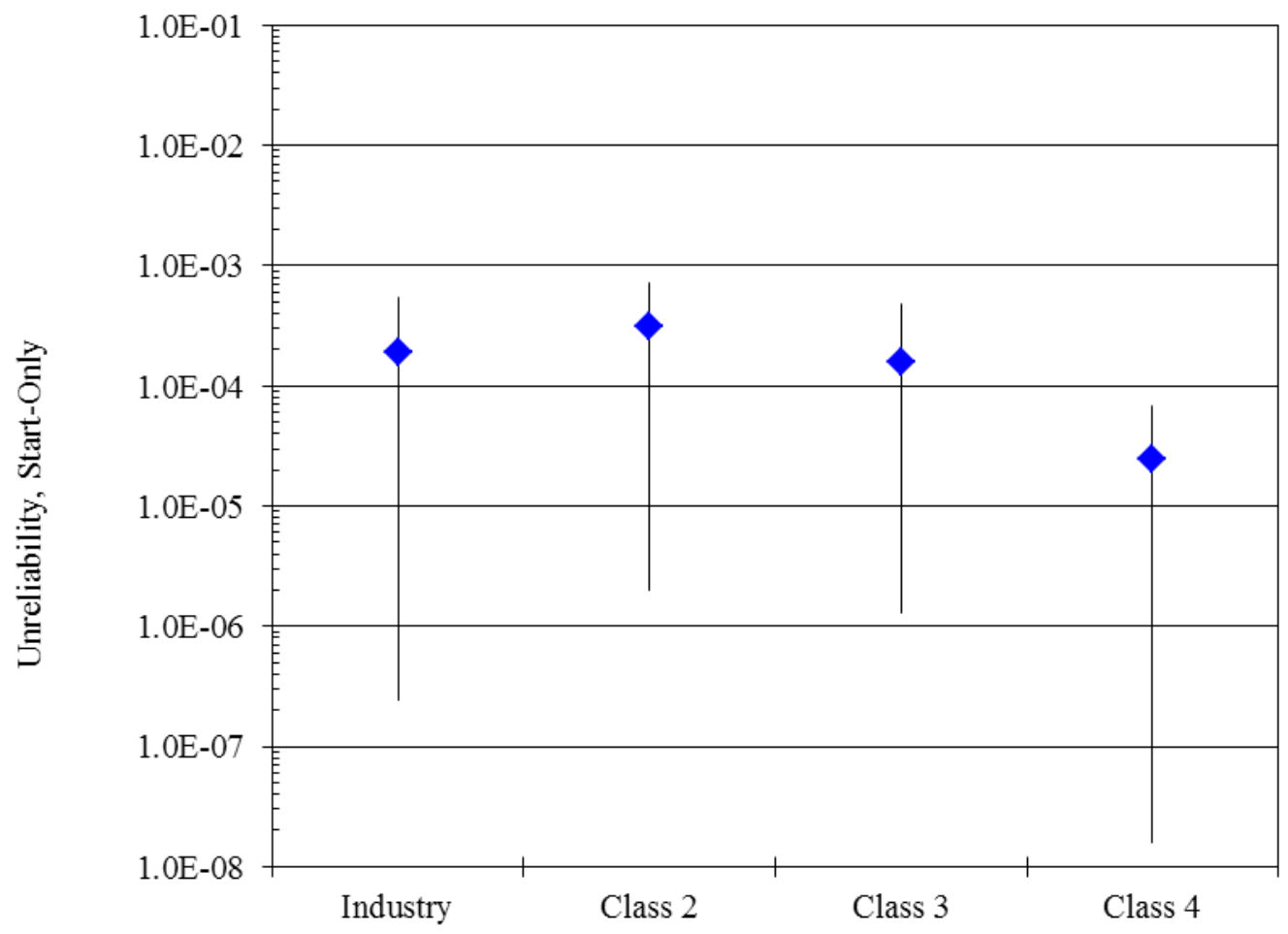

Figure 1. EPS start-only mission unreliability for Class 2, 3, and 4 and industry-wide groupings.

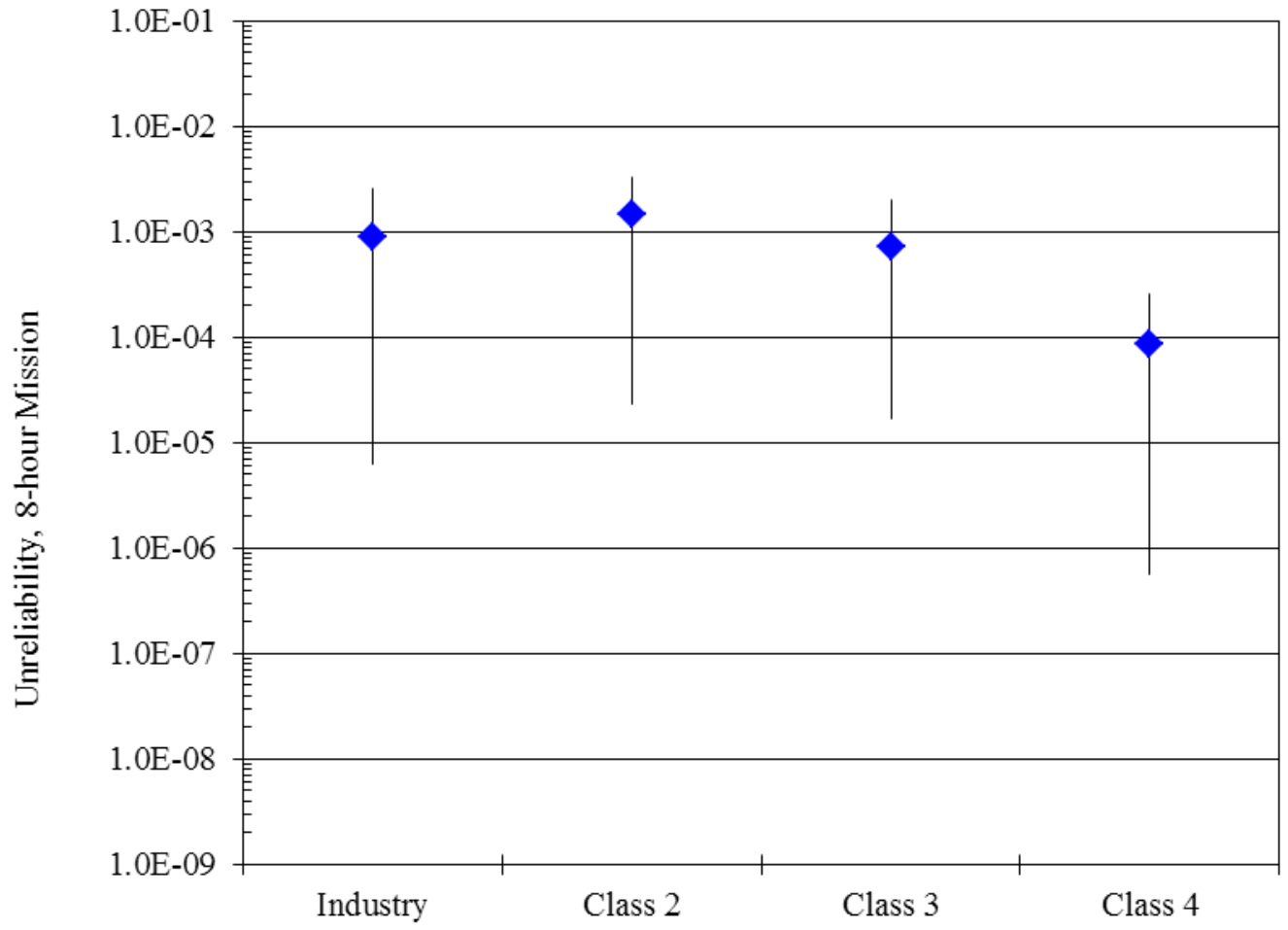

Figure 2. EPS 8-hour mission unreliability for Class 2, 3, and 4 and industry-wide groupings. 


\section{INDUSTRY-WIDE TRENDS}

The yearly (FY-98 through FY-14) failure and demand or run time data were obtained from ICES for the EPS system. EPS train maintenance unavailability data for trending are from the same time period, as reported in the ROP and ICES. The component basic event uncertainty was calculated for the EPS system components using the trending methods described in Section 1 and 2 of the Overview and Reference document. Tables 6 and 7 show the yearly data values for each EPS system specific component and failure mode combination that was varied in the model. These data were loaded into the EPS system fault tree in each SPAR model (see Table 1).

The trend charts show the results of varying component reliability data over time and updating generic, relatively flat prior distributions using data for each year. In addition, for comparison, this update (current SPAR/ICES) is shown. Section 4 of the Overview and Reference link on the System Studies main web page provides more detailed discussion of the trending methods. In the lower left hand corner of the trend figures, the regression method is reported.

The components and failure modes that were varied in the EPS model are

- $\quad$ EPS diesel generator start, run, and test and maintenance.

Figure 3 shows the trend in the EPS start-only model unreliability. Table 4 shows the data points for Figure 3. Figure 4 shows the trend in the 8 -hour mission unreliability. Table 5 shows the data points for Figure 4. 


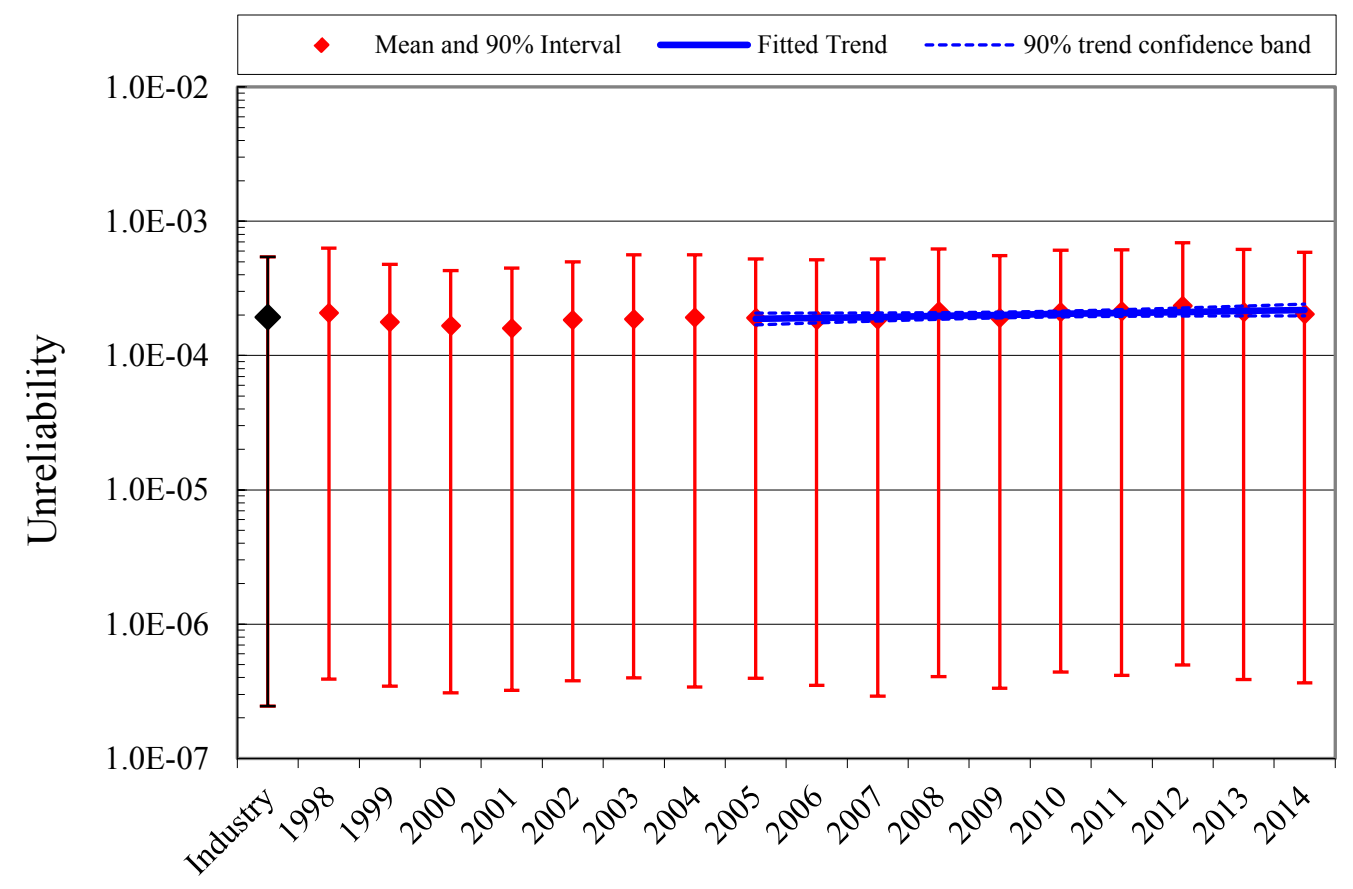

Logit model, $\mathrm{p}$-value $=0.0362 \quad$ Fiscal Year Industry EPS Start-Only 12-15-2015

Figure 3. Trend of EPS system unreliability (start-only model), as a function of fiscal year.

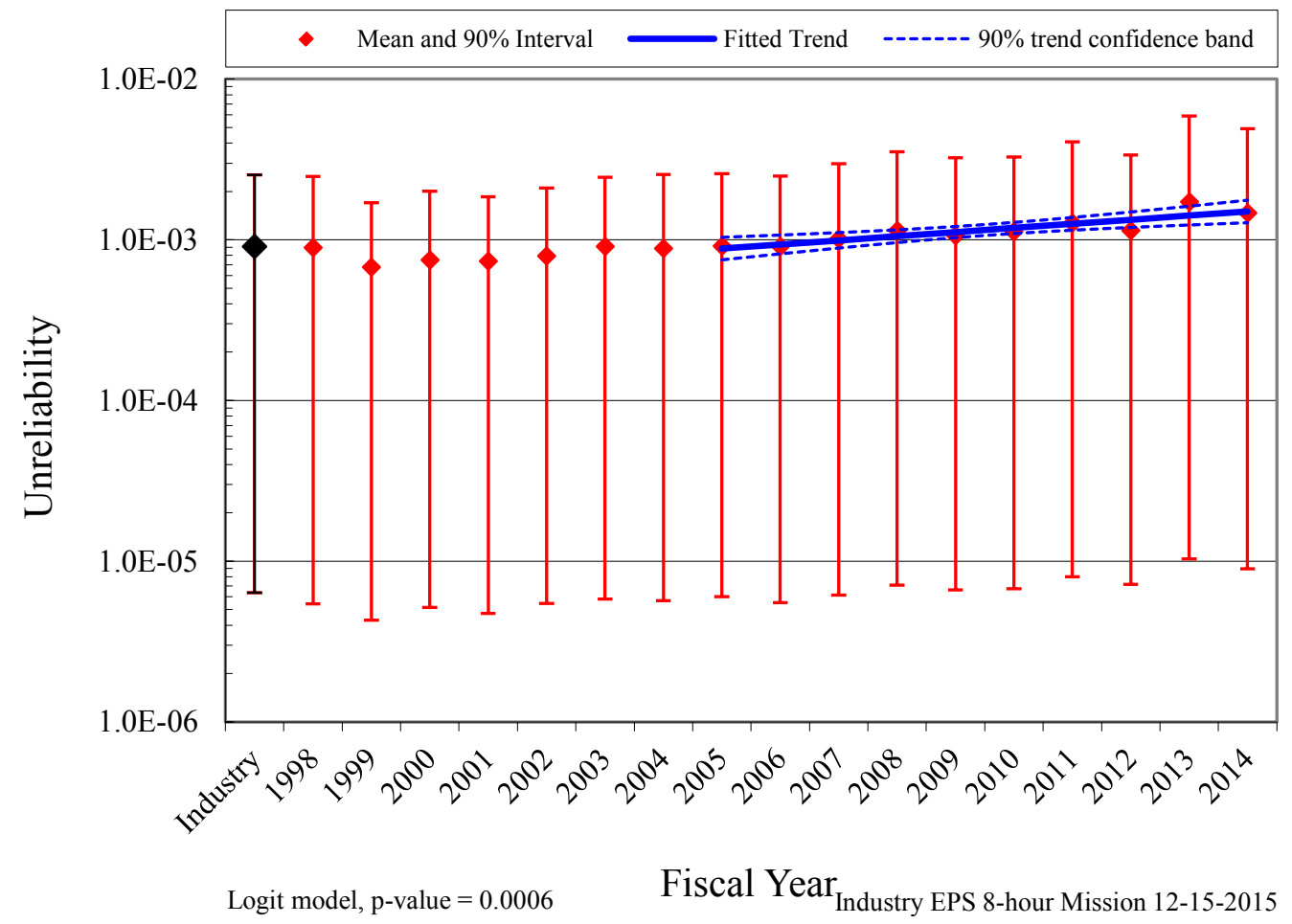

Figure 4. Trend of EPS system unreliability (8-hour model), as a function of fiscal year. 


\section{BASIC EVENT GROUP IMPORTANCES}

The EPS basic event group Fussell-Vesely importances were calculated for the failure to start and 8hour model for each plant using the industry-wide data (1998-2010). These basic event group importances were then averaged across all plants to represent an industry-wide basic event group importance. The industry-wide EPS start-only and 8-hour basic event group importances are shown in Figure 5. In both cases, the leading contributors to EPS system unreliability are the 1E Generator group of basic events and AC Power. In addition, generator auxiliary equipment and the sequencer are important to the start-only model. In addition, cooling and human action are important for the 8-hour mission model. For more discussion on the EPS diesel generators, see the emergency diesel generator component reliability study at NRC Reactor Operational Experience Results and Databases. Table 3 shows the SPAR model EPS importance groups and their descriptions.

The basic event group importances were also averaged across plants of the same EPS class to represent class basic event group importances. The class EPS start-only and 8-hour basic event group importances are shown in Figure 6, Figure 7, and Figure 8. In both cases, for all classes, the leading contributor to EPS system unreliability is the $1 \mathrm{E}$ Generator group of basic events.

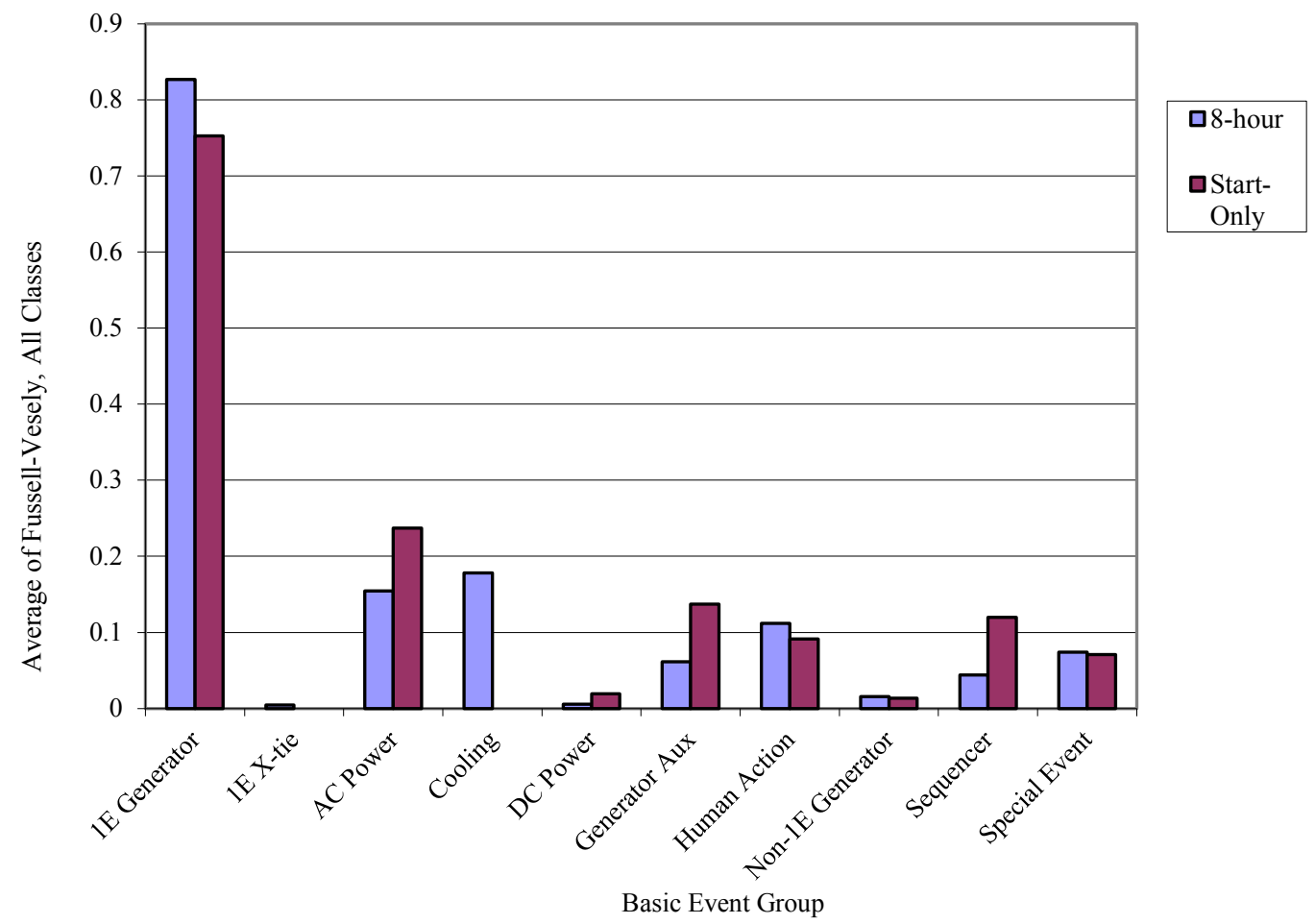

Figure 5. EPS industry-wide basic event group importances. 
Table 3. EPS model basic event importance group descriptions.

Group

1E Generator

1E X-tie

AC Power

Cooling

DC Power

Generator Aux

Human Action

Non 1E Generator

Special Event
Description

All basic events associated with the primary emergency power supplies. Includes diesel, gas turbine, and hydro powered equipment. The start, run, common-cause, and test and maintenance are included in this group of basic events.

Cross-tie or swing $1 \mathrm{E}$ qualified generating equipment available to the EPS in the model.

Buses and circuit breakers in the EPS model.

Cooling support components: service water or component cooling pumps, valves, and heat exchangers.

Buses, circuit breakers, battery chargers, and batteries in the EPS model.

This group includes the emergency power auxiliary components that are explicitly modeled in the EPS system. Includes the fuel oil, starting air, room cooling, and electrical dedicated to the generators.

This group contains the events that allow operator recovery from expected automatic actions.

All basic events associated with the secondary emergency power supplies. Includes diesel, gas turbine, and hydro powered equipment. The start, run, common-cause, and test and maintenance are included in the group of basic events.

The sequencer includes all basic events associated with the sequencer. These are various special events that are added to the model to model plantspecific conditions that affect the EPS.

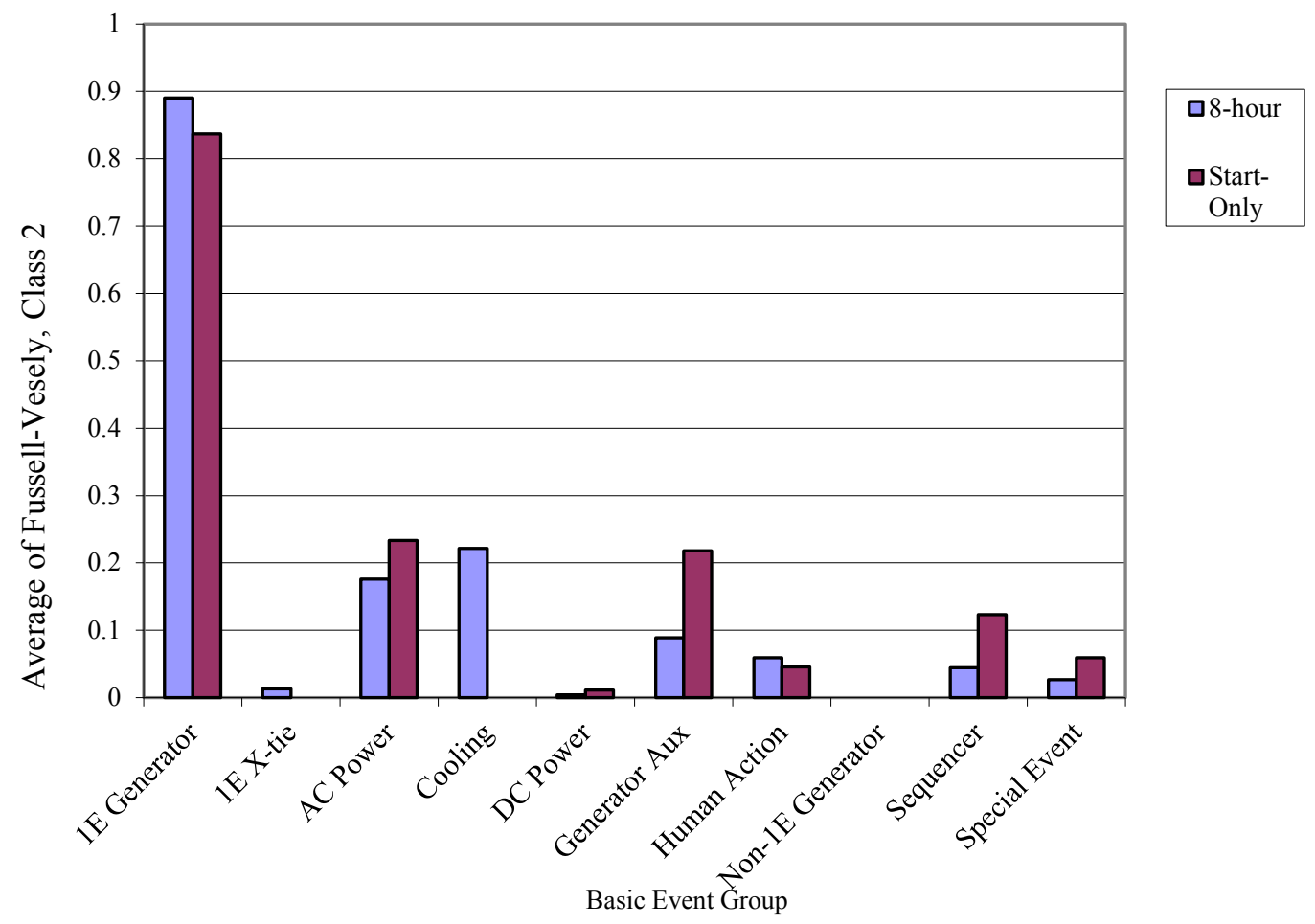

Figure 6. EPS Class 2 basic event group importances. 


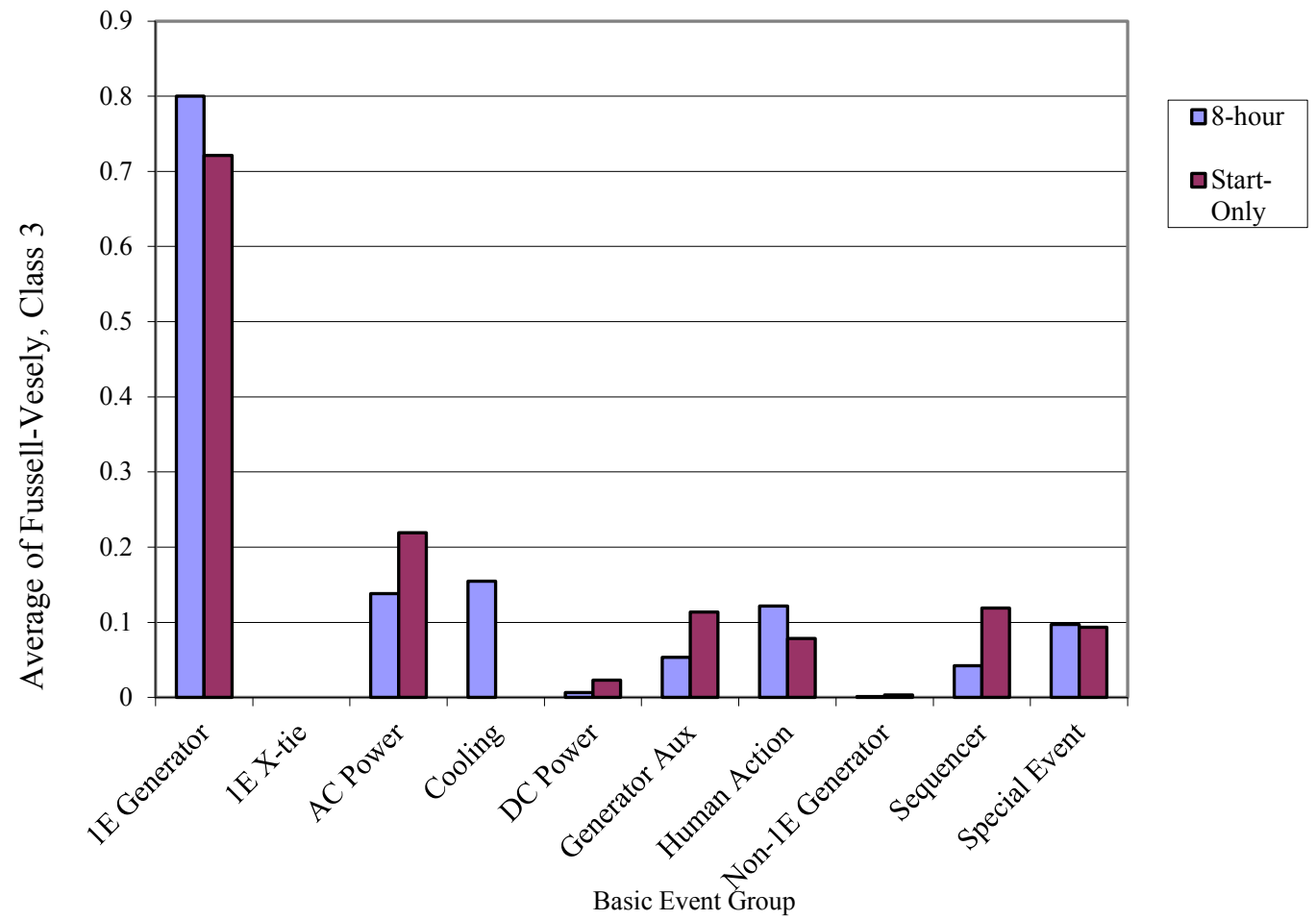

Figure 7. EPS Class 3 basic event group importances.

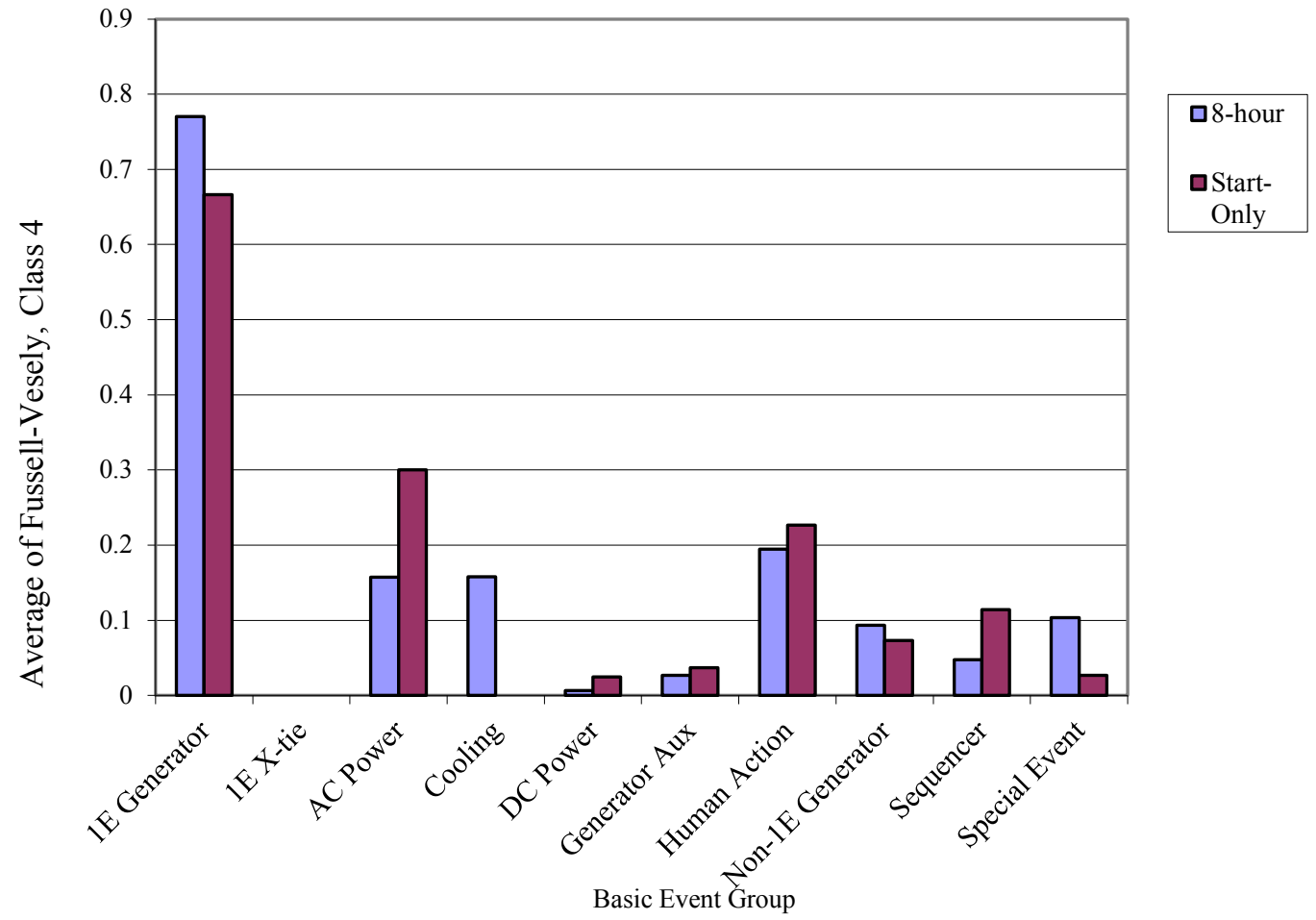

Figure 8. EPS Class 4 basic event group importances. 
System Study

Emergency Power System
2014 Update

December 2015 


\section{DATA TABLES}

Table 4. Plot data for EPS start-only trend, Figure 3.

\begin{tabular}{ccccccc}
\hline & \multicolumn{2}{c}{ Regression Curve Data Points } & \multicolumn{2}{c}{ Annual Estimate Data Points } \\
\cline { 2 - 7 } FY/Source & Mean & $\begin{array}{c}\text { Lower } \\
\mathbf{( 5 \% )}\end{array}$ & $\begin{array}{c}\text { Upper } \\
\mathbf{( 9 5 \% )}\end{array}$ & $\begin{array}{c}\text { Lower } \\
\mathbf{( 5 \% )}\end{array}$ & $\begin{array}{c}\text { Upper } \\
\mathbf{( 9 5 \% )}\end{array}$ & Mean \\
\hline SPAR/ICES & & & & $2.45 \mathrm{E}-07$ & $5.45 \mathrm{E}-04$ & $1.92 \mathrm{E}-04$ \\
1998 & & & & $3.89 \mathrm{E}-07$ & $6.33 \mathrm{E}-04$ & $2.07 \mathrm{E}-04$ \\
1999 & & & & $3.45 \mathrm{E}-07$ & $4.80 \mathrm{E}-04$ & $1.77 \mathrm{E}-04$ \\
\hline 2000 & & & & $3.07 \mathrm{E}-07$ & $4.29 \mathrm{E}-04$ & $1.66 \mathrm{E}-04$ \\
\hline 2001 & & & & $3.20 \mathrm{E}-07$ & $4.47 \mathrm{E}-04$ & $1.59 \mathrm{E}-04$ \\
\hline 2002 & & & & $3.78 \mathrm{E}-07$ & $5.00 \mathrm{E}-04$ & $1.84 \mathrm{E}-04$ \\
\hline 2003 & & & & $3.98 \mathrm{E}-07$ & $5.61 \mathrm{E}-04$ & $1.87 \mathrm{E}-04$ \\
\hline 2004 & & & & $3.40 \mathrm{E}-07$ & $5.62 \mathrm{E}-04$ & $1.92 \mathrm{E}-04$ \\
\hline 2005 & $1.87 \mathrm{E}-04$ & $1.69 \mathrm{E}-04$ & $2.07 \mathrm{E}-04$ & $3.96 \mathrm{E}-07$ & $5.25 \mathrm{E}-04$ & $1.90 \mathrm{E}-04$ \\
\hline 2006 & $1.91 \mathrm{E}-04$ & $1.75 \mathrm{E}-04$ & $2.07 \mathrm{E}-04$ & $3.49 \mathrm{E}-07$ & $5.16 \mathrm{E}-04$ & $1.83 \mathrm{E}-04$ \\
\hline 2007 & $1.94 \mathrm{E}-04$ & $1.81 \mathrm{E}-04$ & $2.08 \mathrm{E}-04$ & $2.91 \mathrm{E}-07$ & $5.25 \mathrm{E}-04$ & $1.84 \mathrm{E}-04$ \\
\hline 2008 & $1.97 \mathrm{E}-04$ & $1.86 \mathrm{E}-04$ & $2.09 \mathrm{E}-04$ & $4.05 \mathrm{E}-07$ & $6.21 \mathrm{E}-04$ & $2.12 \mathrm{E}-04$ \\
\hline 2009 & $2.01 \mathrm{E}-04$ & $1.91 \mathrm{E}-04$ & $2.11 \mathrm{E}-04$ & $3.32 \mathrm{E}-07$ & $5.55 \mathrm{E}-04$ & $1.90 \mathrm{E}-04$ \\
\hline 2010 & $2.04 \mathrm{E}-04$ & $1.94 \mathrm{E}-04$ & $2.14 \mathrm{E}-04$ & $4.39 \mathrm{E}-07$ & $6.09 \mathrm{E}-04$ & $2.10 \mathrm{E}-04$ \\
\hline 2011 & $2.08 \mathrm{E}-04$ & $1.96 \mathrm{E}-04$ & $2.20 \mathrm{E}-04$ & $4.14 \mathrm{E}-07$ & $6.16 \mathrm{E}-04$ & $2.12 \mathrm{E}-04$ \\
\hline 2012 & $2.11 \mathrm{E}-04$ & $1.97 \mathrm{E}-04$ & $2.26 \mathrm{E}-04$ & $4.97 \mathrm{E}-07$ & $6.93 \mathrm{E}-04$ & $2.34 \mathrm{E}-04$ \\
\hline 2013 & $2.15 \mathrm{E}-04$ & $1.97 \mathrm{E}-04$ & $2.34 \mathrm{E}-04$ & $3.88 \mathrm{E}-07$ & $6.18 \mathrm{E}-04$ & $2.09 \mathrm{E}-04$ \\
\hline 2014 & $2.18 \mathrm{E}-04$ & $1.98 \mathrm{E}-04$ & $2.42 \mathrm{E}-04$ & $3.65 \mathrm{E}-07$ & $5.87 \mathrm{E}-04$ & $2.03 \mathrm{E}-04$ \\
\hline
\end{tabular}


Table 5. Plot data for EPS 8-hour trend, Figure 4.

\begin{tabular}{ccccccc}
\hline & \multicolumn{2}{c}{ Regression Curve Data Points } & \multicolumn{3}{c}{ Annual Estimate Data Points } \\
\cline { 2 - 7 } FY/Source & Mean & $\begin{array}{c}\text { Lower } \\
\mathbf{( 5 \% )}\end{array}$ & $\begin{array}{c}\text { Upper } \\
\mathbf{( 9 5 \% )}\end{array}$ & $\begin{array}{c}\text { Lower } \\
\mathbf{( 5 \% )}\end{array}$ & $\begin{array}{c}\text { Upper } \\
\mathbf{( 9 5 \% )}\end{array}$ & Mean \\
\hline SPAR/ICES & & & & $6.37 \mathrm{E}-06$ & $2.54 \mathrm{E}-03$ & $9.07 \mathrm{E}-04$ \\
1998 & & & & $5.43 \mathrm{E}-06$ & $2.48 \mathrm{E}-03$ & $8.88 \mathrm{E}-04$ \\
\hline 1999 & & & & $4.31 \mathrm{E}-06$ & $1.71 \mathrm{E}-03$ & $6.72 \mathrm{E}-04$ \\
\hline 2000 & & & & $5.16 \mathrm{E}-06$ & $2.00 \mathrm{E}-03$ & $7.47 \mathrm{E}-04$ \\
\hline 2001 & & & & $4.72 \mathrm{E}-06$ & $1.85 \mathrm{E}-03$ & $7.33 \mathrm{E}-04$ \\
2002 & & & & $5.44 \mathrm{E}-06$ & $2.10 \mathrm{E}-03$ & $7.92 \mathrm{E}-04$ \\
\hline 2003 & & & & $5.82 \mathrm{E}-06$ & $2.45 \mathrm{E}-03$ & $9.05 \mathrm{E}-04$ \\
\hline 2004 & & & & $5.68 \mathrm{E}-06$ & $2.55 \mathrm{E}-03$ & $8.78 \mathrm{E}-04$ \\
\hline 2005 & $8.82 \mathrm{E}-04$ & $7.50 \mathrm{E}-04$ & $1.04 \mathrm{E}-03$ & $6.02 \mathrm{E}-06$ & $2.58 \mathrm{E}-03$ & $9.12 \mathrm{E}-04$ \\
\hline 2006 & $9.36 \mathrm{E}-04$ & $8.18 \mathrm{E}-04$ & $1.07 \mathrm{E}-03$ & $5.53 \mathrm{E}-06$ & $2.49 \mathrm{E}-03$ & $9.05 \mathrm{E}-04$ \\
\hline 2007 & $9.93 \mathrm{E}-04$ & $8.89 \mathrm{E}-04$ & $1.11 \mathrm{E}-03$ & $6.16 \mathrm{E}-06$ & $2.98 \mathrm{E}-03$ & $1.01 \mathrm{E}-03$ \\
\hline 2008 & $1.05 \mathrm{E}-03$ & $9.61 \mathrm{E}-04$ & $1.15 \mathrm{E}-03$ & $7.10 \mathrm{E}-06$ & $3.53 \mathrm{E}-03$ & $1.14 \mathrm{E}-03$ \\
\hline 2009 & $1.12 \mathrm{E}-03$ & $1.03 \mathrm{E}-03$ & $1.21 \mathrm{E}-03$ & $6.61 \mathrm{E}-06$ & $3.24 \mathrm{E}-03$ & $1.06 \mathrm{E}-03$ \\
\hline 2010 & $1.19 \mathrm{E}-03$ & $1.09 \mathrm{E}-03$ & $1.28 \mathrm{E}-03$ & $6.73 \mathrm{E}-06$ & $3.28 \mathrm{E}-03$ & $1.12 \mathrm{E}-03$ \\
\hline 2011 & $1.26 \mathrm{E}-03$ & $1.15 \mathrm{E}-03$ & $1.38 \mathrm{E}-03$ & $8.00 \mathrm{E}-06$ & $4.06 \mathrm{E}-03$ & $1.27 \mathrm{E}-03$ \\
\hline 2012 & $1.33 \mathrm{E}-03$ & $1.19 \mathrm{E}-03$ & $1.49 \mathrm{E}-03$ & $7.19 \mathrm{E}-06$ & $3.38 \mathrm{E}-03$ & $1.14 \mathrm{E}-03$ \\
\hline 2013 & $1.42 \mathrm{E}-03$ & $1.24 \mathrm{E}-03$ & $1.62 \mathrm{E}-03$ & $1.04 \mathrm{E}-05$ & $5.90 \mathrm{E}-03$ & $1.72 \mathrm{E}-03$ \\
\hline 2014 & $1.50 \mathrm{E}-03$ & $1.28 \mathrm{E}-03$ & $1.76 \mathrm{E}-03$ & $8.97 \mathrm{E}-06$ & $4.91 \mathrm{E}-03$ & $1.47 \mathrm{E}-03$ \\
\hline
\end{tabular}


Table 6. Basic event reliability trending data.

\begin{tabular}{|c|c|c|c|c|c|c|c|c|}
\hline \multirow{2}{*}{$\begin{array}{l}\text { Failure } \\
\text { Mode }\end{array}$} & \multirow[b]{2}{*}{ Component } & \multirow[b]{2}{*}{ Year } & \multirow{2}{*}{$\begin{array}{c}\text { Number } \\
\text { of } \\
\text { Failures }\end{array}$} & \multirow{2}{*}{$\begin{array}{l}\text { Demands/ } \\
\text { Run Hours }\end{array}$} & \multicolumn{4}{|c|}{ Bayesian Update } \\
\hline & & & & & Mean & Post A & Post B & Distribution \\
\hline FTLR & GEN & 1998 & 20 & 3807 & 5.02E-03 & 22.8 & 4518 & Beta \\
\hline FTLR & GEN & 1999 & 9 & 3752 & $2.62 \mathrm{E}-03$ & 11.8 & 4474 & Beta \\
\hline FTLR & GEN & 2000 & 11 & 3761 & 3.06E-03 & 13.8 & 4482 & Beta \\
\hline FTLR & GEN & 2001 & 8 & 3711 & 2.42E-03 & 10.8 & 4434 & Beta \\
\hline FTLR & GEN & 2002 & 18 & 3709 & 4.68E-03 & 20.8 & 4422 & Beta \\
\hline FTLR & GEN & 2003 & 16 & 3714 & 4.22E-03 & 18.8 & 4429 & Beta \\
\hline FTLR & GEN & 2004 & 14 & 3781 & 3.72E-03 & 16.8 & 4498 & Beta \\
\hline FTLR & GEN & 2005 & 11 & 3805 & 3.03E-03 & 13.8 & 4525 & Beta \\
\hline FTLR & GEN & 2006 & 16 & 3707 & 4.23E-03 & 18.8 & 4422 & Beta \\
\hline FTLR & GEN & 2007 & 21 & 3683 & 5.38E-03 & 23.8 & 4393 & Beta \\
\hline FTLR & GEN & 2008 & 17 & 3709 & 4.45E-03 & 19.8 & 4423 & Beta \\
\hline FTLR & GEN & 2009 & 19 & 3595 & 5.03E-03 & 21.8 & 4307 & Beta \\
\hline FTLR & GEN & 2010 & 13 & 3697 & 3.56E-03 & 15.8 & 4415 & Beta \\
\hline FTLR & GEN & 2011 & 14 & 3646 & 3.83E-03 & 16.8 & 4363 & Beta \\
\hline FTLR & GEN & 2012 & 11 & 3486 & $3.26 \mathrm{E}-03$ & 13.8 & 4207 & Beta \\
\hline FTLR & GEN & 2013 & 14 & 3570 & 3.90E-03 & 16.8 & 4287 & Beta \\
\hline FTLR & GEN & 2014 & 12 & 3445 & 3.54E-03 & 14.8 & 4164 & Beta \\
\hline FTR & GEN & 1998 & 4 & 6779 & 7.52E-04 & 7.6 & 10046 & Gamma \\
\hline FTR & GEN & 1999 & 0 & 6928 & 3.48E-04 & 3.6 & 10195 & Gamma \\
\hline FTR & GEN & 2000 & 6 & 7787 & 8.64E-04 & 9.6 & 11054 & Gamma \\
\hline FTR & GEN & 2001 & 4 & 8162 & 6.61E-04 & 7.6 & 11429 & Gamma \\
\hline FTR & GEN & 2002 & 6 & 8761 & 7.94E-04 & 9.6 & 12028 & Gamma \\
\hline FTR & GEN & 2003 & 8 & 8717 & 9.64E-04 & 11.6 & 11984 & Gamma \\
\hline FTR & GEN & 2004 & 9 & 8935 & 1.03E-03 & 12.6 & 12202 & Gamma \\
\hline FTR & GEN & 2005 & 12 & 9536 & 1.21E-03 & 15.6 & 12803 & Gamma \\
\hline FTR & GEN & 2006 & 9 & 8740 & 1.05E-03 & 12.6 & 12007 & Gamma \\
\hline FTR & GEN & 2007 & 14 & 9018 & 1.43E-03 & 17.6 & 12285 & Gamma \\
\hline FTR & GEN & 2008 & 16 & 8006 & 1.73E-03 & 19.6 & 11273 & Gamma \\
\hline FTR & GEN & 2009 & 15 & 8048 & 1.64E-03 & 18.6 & 11315 & Gamma \\
\hline FTR & GEN & 2010 & 14 & 7880 & 1.57E-03 & 17.6 & 11147 & Gamma \\
\hline FTR & GEN & 2011 & 23 & 8738 & 2.21E-03 & 26.6 & 12005 & Gamma \\
\hline FTR & GEN & 2012 & 9 & 5298 & 1.47E-03 & 12.6 & 8565 & Gamma \\
\hline FTR & GEN & 2013 & 26 & 5405 & 3.41E-03 & 29.6 & 8672 & Gamma \\
\hline FTR & GEN & 2014 & 18 & 4429 & 2.80E-03 & 21.6 & 7696 & Gamma \\
\hline FTS & GEN & 1998 & 14 & 4177 & 3.17E-03 & 22.1 & 6961 & Beta \\
\hline FTS & GEN & 1999 & 12 & 4200 & 2.87E-03 & 20.1 & 6986 & Beta \\
\hline FTS & GEN & 2000 & 10 & 3986 & 2.67E-03 & 18.1 & 6774 & Beta \\
\hline FTS & GEN & 2001 & 11 & 4012 & 2.80E-03 & 19.1 & 6799 & Beta \\
\hline FTS & GEN & 2002 & 15 & 4358 & 3.23E-03 & 23.1 & 7141 & Beta \\
\hline FTS & GEN & 2003 & 15 & 4315 & $3.25 E-03$ & 23.1 & 7098 & Beta \\
\hline
\end{tabular}


Table 6. (continued).

\begin{tabular}{|c|c|c|c|c|c|c|c|c|}
\hline \multirow{2}{*}{$\begin{array}{l}\text { Failure } \\
\text { Mode }\end{array}$} & \multirow[b]{2}{*}{ Component } & \multirow[b]{2}{*}{ Year } & \multirow{2}{*}{$\begin{array}{l}\text { Number } \\
\text { of } \\
\text { Failures }\end{array}$} & \multirow{2}{*}{$\begin{array}{l}\text { Demands/ } \\
\text { Run Hours }\end{array}$} & \multicolumn{4}{|c|}{ Bayesian Update } \\
\hline & & & & & Mean & Post A & Post B & Distribution \\
\hline FTS & GEN & 2004 & 13 & 4428 & 2.92E-03 & 21.1 & 7213 & Beta \\
\hline FTS & GEN & 2005 & 16 & 4399 & 3.35E-03 & 24.1 & 7181 & Beta \\
\hline FTS & GEN & 2006 & 11 & 4292 & 2.69E-03 & 19.1 & 7079 & Beta \\
\hline FTS & GEN & 2007 & 7 & 4333 & 2.12E-03 & 15.1 & 7124 & Beta \\
\hline FTS & GEN & 2008 & 14 & 4365 & 3.08E-03 & 22.1 & 7149 & Beta \\
\hline FTS & GEN & 2009 & 9 & 4174 & $2.45 \mathrm{E}-03$ & 17.1 & 6963 & Beta \\
\hline FTS & GEN & 2010 & 17 & 4230 & 3.57E-03 & 25.1 & 7011 & Beta \\
\hline FTS & GEN & 2011 & 15 & 4201 & 3.30E-03 & 23.1 & 6984 & Beta \\
\hline FTS & GEN & 2012 & 19 & 3958 & 4.01E-03 & 27.1 & 6737 & Beta \\
\hline FTS & GEN & 2013 & 13 & 4107 & 3.05E-03 & 21.1 & 6892 & Beta \\
\hline FTS & GEN & 2014 & 11 & 3975 & 2.82E-03 & 19.1 & 6762 & Beta \\
\hline
\end{tabular}

Table 7. Basic event UA trending data.

\begin{tabular}{|c|c|c|c|c|c|c|c|c|}
\hline \multirow{2}{*}{$\begin{array}{c}\text { Failure } \\
\text { Mode }\end{array}$} & \multirow[b]{2}{*}{ Component } & \multirow[b]{2}{*}{ Year } & \multirow{2}{*}{$\begin{array}{c}\text { UA } \\
\text { Hours }\end{array}$} & \multirow{2}{*}{$\begin{array}{l}\text { Critical } \\
\text { Hours }\end{array}$} & \multicolumn{4}{|c|}{ Bayesian Update } \\
\hline & & & & & Mean & Post A & Post B & Distribution \\
\hline UA & EDG & 1998 & 22880 & 1388150 & $1.66 \mathrm{E}-02$ & 1.339 & 79.3 & Beta \\
\hline UA & EDG & 1999 & 23400 & 1985627 & 1.17E-02 & 2.659 & 224.5 & Beta \\
\hline UA & EDG & 2000 & 18405 & 2051800 & $9.36 \mathrm{E}-03$ & 3.075 & 325.5 & Beta \\
\hline UA & EDG & 2001 & 19096 & 2063455 & $9.90 \mathrm{E}-03$ & 1.649 & 165.0 & Beta \\
\hline UA & EDG & 2002 & 23651 & 2087422 & 1.16E-02 & 2.320 & 198.1 & Beta \\
\hline UA & EDG & 2003 & 27824 & 2051652 & $1.35 \mathrm{E}-02$ & 1.563 & 114.3 & Beta \\
\hline UA & EDG & 2004 & 30926 & 2102001 & $1.41 \mathrm{E}-02$ & 1.003 & 70.0 & Beta \\
\hline UA & EDG & 2005 & 24607 & 2059515 & 1.19E-02 & 2.662 & 220.2 & Beta \\
\hline UA & EDG & 2006 & 28741 & 2096727 & 1.35E-02 & 1.803 & 131.4 & Beta \\
\hline UA & EDG & 2007 & 31475 & 2091220 & 1.49E-02 & 1.866 & 123.3 & Beta \\
\hline UA & EDG & 2008 & 34612 & 2088040 & 1.66E-02 & 2.147 & 127.5 & Beta \\
\hline UA & EDG & 2009 & 33146 & 2086914 & $1.58 \mathrm{E}-02$ & 2.501 & 156.2 & Beta \\
\hline UA & EDG & 2010 & 30683 & 2061553 & 1.49E-02 & 2.326 & 153.9 & Beta \\
\hline UA & EDG & 2011 & 31131 & 2026957 & $1.54 \mathrm{E}-02$ & 2.725 & 174.3 & Beta \\
\hline UA & EDG & 2012 & 35049 & 2008250 & 1.69E-02 & 1.914 & 111.3 & Beta \\
\hline UA & EDG & 2013 & 31132 & 1976666 & 0.0148701 & 2.119 & 140.4 & Beta \\
\hline UA & EDG & 2014 & 31142 & 2024242 & 1.53E-02 & 2.675 & 172.5 & Beta \\
\hline
\end{tabular}


Table 8. Failure mode acronyms.

\begin{tabular}{ll}
\hline \multicolumn{1}{c}{ Failure Mode } & \multicolumn{1}{c}{ Failure Mode Description } \\
\hline FTLR & Fail to load/run \\
FTOC & Fail to open/close \\
FTOP & Fail to operate \\
FTR & Fail to run \\
FTR $<1$ H & Fail to run less than one hour (after start) \\
FTS & Fail to start \\
SO & Spurious operation \\
UA & Unavailability (maintenance or state of another component) \\
\hline
\end{tabular}


System Study

Emergency Power System
2014 Update

December 2015 


\section{SYSTEM DESCRIPTION}

The EPS is designed to provide backup, onsite ac power to vital buses given a LOOP until offsite power can be restored to the plant. EPS designs vary widely among the 104 U.S. commercial nuclear power plants. A summary of those designs is presented in Table 9. Typical EPS designs include two, three, or four EDGs, with only one of the EDGs required for success. However, as indicated in Table 9, there are many variations of these typical designs, including shared EDGs and/or the ability to cross-tie to other EDGs (at multi-plant sites), and availability of alternate ac sources such as gas turbine generators (GTGs) or hydro turbine generators (HTGs). In addition, several of the plants require two EDGs for long-term success, rather than one.

SPAR modeling of the EPS incorporates the plant-to-plant design and operational differences indicated in Table 9. Table 9 shows the generating equipment used in the EPS SPAR model. In some cases, two models use the same equipment. These are repeated for each entry to show how the SPAR models calculate. All ac emergency power sources that either are automatically started and aligned to essential buses given a LOOP or can be manually started and aligned within approximately 30 minutes are included in the EPS SPAR fault trees. Additional emergency power sources such as GTGs or HTGs that require more than 30 minutes to start and align to essential buses are included in other parts of the SBO event tree, typically as additional credit for recovery of ac power. Included in the EPS SPAR fault trees are dependencies such as room cooling, service water cooling, and dc power.

The typical EPS consists of two or more emergency power sources, usually diesel generators, connected to two or more vital or safety buses. These vital buses power equipment needed for safe shutdown during most transients that are postulated at nuclear power plants.

Figure 9 shows the simplest EPS configuration. Variations are: more buses, usually with their own emergency power sources, swing power sources that can power vital buses at either of two units, and alternate emergency power sources typically referred to as station blackout generators.

The SPAR models of the EPS include many more components than those shown in Figure 9. Most of these components are related to the support needed for the emergency power source success. Some of these are explicitly modeled in SPAR if there is a common-mode failure of multiple generators. Generally, these include

Cooling - Cooling is required to remove heat from the lubricating oil and the engine itself. Cooling is provided by service water either directly or through a closed loop cooling system such as component cooling water. Some emergency power sources have dedicated cooling systems that are independent of the service water systems.

Room Cooling - Room cooling is usually required for extended performance of the EPS. The room cooling is provided by air conditioning heat exchangers that may be cooled by a chilled water source.

Fuel Oil-Fuel oil is usually provided from a common fuel oil tank to separate 'day tanks' for each emergency power source. Pumps, valves, and instrumentation are required to maintain day tank levels and to supply fuel oil to the engine itself.

Sequencer-The sequencer strips loads from the dead bus prior to attempting to load the bus with the emergency power source. Then the sequencer sequences loads back onto the bus once it has been reenergized.

dc Power - dc power is provided by the vital batteries. DC power provides the energy to operate breakers and powers the control circuitry for the EPS. 
Table 9. EPS configurations at U.S. commercial nuclear power plants.

\begin{tabular}{|c|c|c|c|c|c|}
\hline Class & Plant & Total & 1E Generator & 1E X-tie & $\begin{array}{l}\text { Non-1E } \\
\text { Generator }\end{array}$ \\
\hline Class 2 & Beaver Valley 1 & 2 & 2 & 2 & \\
\hline Class 2 & Beaver Valley 2 & 2 & 2 & 2 & \\
\hline Class 2 & Brunswick 1 & 4 & 2 & 2 & \\
\hline Class 2 & Brunswick 2 & 4 & 2 & 2 & \\
\hline Class 2 & Callaway & 2 & 2 & & \\
\hline Class 2 & Clinton 1 & 2 & 2 & & \\
\hline Class 2 & Columbia 2 & 2 & 2 & & \\
\hline Class 2 & Comanche Peak 1 & 2 & 2 & & \\
\hline Class 2 & Comanche Peak 2 & 2 & 2 & & \\
\hline Class 2 & Cook 1 & 2 & 2 & & \\
\hline Class 2 & Cook 2 & 2 & 2 & & \\
\hline Class 2 & Cooper & 2 & 2 & & \\
\hline Class 2 & Crystal River 3 & 2 & 2 & & \\
\hline Class 2 & Davis-Besse & 2 & 2 & & \\
\hline Class 2 & Duane Arnold & 2 & 2 & & \\
\hline Class 2 & Fort Calhoun & 2 & 2 & & \\
\hline Class 2 & Ginna & 2 & 2 & & \\
\hline Class 2 & Grand Gulf & 2 & 2 & & \\
\hline Class 2 & Harris & 2 & 2 & & \\
\hline Class 2 & Kewaunee & 2 & 2 & & \\
\hline Class 2 & McGuire 1 & 2 & 2 & & \\
\hline Class 2 & McGuire 2 & 2 & 2 & & \\
\hline Class 2 & Monticello & 2 & 2 & & \\
\hline Class 2 & Nine Mile Pt. 1 & 2 & 2 & & \\
\hline Class 2 & Nine Mile Pt. 2 & 2 & 2 & & \\
\hline Class 2 & Oconee 1 & 2 & 1 & 1 & \\
\hline Class 2 & Oconee 2 & 2 & 1 & 1 & \\
\hline Class 2 & Oconee 3 & 2 & 1 & 1 & \\
\hline Class 2 & Oyster Creek & 2 & 2 & & \\
\hline Class 2 & Palisades & 2 & 2 & & \\
\hline Class 2 & Perry & 2 & 2 & & \\
\hline Class 2 & Pilgrim & 2 & 2 & & \\
\hline Class 2 & Robinson 2 & 3 & 2 & & 1 \\
\hline Class 2 & Seabrook & 2 & 2 & & \\
\hline Class 2 & Summer & 2 & 2 & & \\
\hline Class 2 & Vermont Yankee & 2 & 2 & & \\
\hline Class 2 & Waterford 3 & 2 & 2 & & \\
\hline Class 2 & Wolf Creek & 2 & 2 & & \\
\hline Class 3 & Arkansas 1 & 3 & 2 & & 1 \\
\hline Class 3 & Arkansas 2 & 3 & 2 & & 1 \\
\hline Class 3 & Braidwood 1 & 4 & 4 & & \\
\hline
\end{tabular}


Table 9. (continued).

\begin{tabular}{|c|c|c|c|c|c|}
\hline Class & Plant & Total & 1E Generator & 1E X-tie & $\begin{array}{l}\text { Non-1E } \\
\text { Generator }\end{array}$ \\
\hline Class 3 & Braidwood 2 & 4 & 4 & & \\
\hline Class 3 & Byron 1 & 4 & 2 & 2 & \\
\hline Class 3 & Byron 2 & 4 & 2 & 2 & \\
\hline Class 3 & Calvert Cliffs 1 & 5 & 2 & 2 & 1 \\
\hline Class 3 & Calvert Cliffs 2 & 5 & 2 & 2 & 1 \\
\hline Class 3 & Catawba 1 & 4 & 2 & 2 & \\
\hline Class 3 & Catawba 2 & 4 & 2 & 2 & \\
\hline Class 3 & Diablo Canyon 1 & 3 & 3 & & \\
\hline Class 3 & Diablo Canyon 2 & 3 & 3 & & \\
\hline Class 3 & Farley 1 & 5 & 3 & 2 & \\
\hline Class 3 & Farley 2 & 5 & 3 & 2 & \\
\hline Class 3 & Hatch 1 & 5 & 3 & 2 & \\
\hline Class 3 & Hatch 2 & 5 & 3 & 2 & \\
\hline Class 3 & Hope Creek & 4 & 4 & & \\
\hline Class 3 & Indian Point 2 & 3 & 3 & & \\
\hline Class 3 & Indian Point 3 & 3 & 3 & & \\
\hline Class 3 & La Salle 1 & 4 & 2 & 2 & \\
\hline Class 3 & La Salle 2 & 4 & 2 & 2 & \\
\hline Class 3 & Millstone 2 & 3 & 2 & & 1 \\
\hline Class 3 & Millstone 3 & 3 & 2 & & 1 \\
\hline Class 3 & Palo Verde 1 & 8 & 2 & $\begin{array}{c}4 \text { (not effective in } \\
\text { model) }\end{array}$ & 2 (need both) \\
\hline Class 3 & Palo Verde 2 & 8 & 2 & $\begin{array}{c}4 \text { (not effective in } \\
\text { model) }\end{array}$ & 2 (need both) \\
\hline Class 3 & Palo Verde 3 & 8 & 2 & $\begin{array}{c}4 \text { (not effective in } \\
\text { model) }\end{array}$ & 2 (need both) \\
\hline Class 3 & Peach Bottom 2 & 4 & $4(2$ of 4$)$ & & \\
\hline Class 3 & Peach Bottom 3 & 4 & $4(2$ of 4$)$ & & \\
\hline Class 3 & River Bend & 3 & 3 (C EDG is different) & & 1 \\
\hline Class 3 & Salem 1 & 4 & 3 & & 1 \\
\hline Class 3 & Salem 2 & 4 & 3 & & 1 \\
\hline Class 3 & San Onofre 2 & 4 & 2 & 2 & \\
\hline Class 3 & San Onofre 3 & 4 & 2 & 2 & \\
\hline Class 3 & Sequoyah 1 & 4 & 2 & 2 & \\
\hline Class 3 & Sequoyah 2 & 4 & 2 & 2 & \\
\hline Class 3 & South Texas 1 & 3 & 3 & & \\
\hline Class 3 & South Texas 2 & 3 & 3 & & \\
\hline Class 3 & St. Lucie 1 & 4 & 2 & 2 & \\
\hline Class 3 & St. Lucie 2 & 4 & 2 & 2 & \\
\hline Class 3 & Surry 1 & 4 & 3 & & 1 \\
\hline Class 3 & Surry 2 & 4 & 3 & & 1 \\
\hline Class 3 & Susquehanna 1 & 5 & 5 (2 of the EDGs cannot & & \\
\hline
\end{tabular}


Table 9. (continued).

\begin{tabular}{|c|c|c|c|c|c|}
\hline Class & Plant & Total & 1E Generator & $1 E X$-tie & $\begin{array}{l}\text { Non-1E } \\
\text { Generator }\end{array}$ \\
\hline \multicolumn{6}{|c|}{ support all loads) } \\
\hline Class 3 & Susquehanna 2 & 5 & $\begin{array}{l}5 \text { (2 of the EDGs cannot } \\
\text { support all loads) }\end{array}$ & & \\
\hline Class 3 & Three Mile IsI 1 & 3 & 2 & & 1 \\
\hline Class 3 & Turkey Point 3 & 4 & 2 & 2 & \\
\hline Class 3 & Turkey Point 4 & 4 & 2 & 2 & \\
\hline Class 3 & Vogtle 1 & 3 & 2 & 1 & \\
\hline Class 3 & Vogtle 2 & 3 & 2 & 1 & \\
\hline Class 3 & Watts Bar 1 & 4 & 2 & 2 & \\
\hline Class 4 & Browns Ferry 1 & 8 & 4 & 4 & \\
\hline Class 4 & Browns Ferry 2 & 6 & 4 & 2 & \\
\hline Class 4 & Browns Ferry 3 & 8 & 4 & 4 & \\
\hline Class 4 & Dresden 2 & 5 & 2 & 1 & 2 \\
\hline Class 4 & Dresden 3 & 5 & 2 & 1 & 2 \\
\hline Class 4 & Fermi 2 & 9 & 4 & & 5 \\
\hline Class 4 & FitzPatrick & 4 & 4 & & \\
\hline Class 4 & Limerick 1 & 6 & 4 & 2 & \\
\hline Class 4 & Limerick 2 & 6 & 4 & 2 & \\
\hline Class 4 & North Anna 1 & 5 & 2 & 2 & 1 \\
\hline Class 4 & North Anna 2 & 5 & 2 & 2 & 1 \\
\hline Class 4 & Point Beach 1 & 5 & 4 & & 1 \\
\hline Class 4 & Point Beach 2 & 5 & 4 & & 1 \\
\hline Class 4 & Prairie Island 1 & 4 & 2 & 2 & \\
\hline Class 4 & Prairie Island 2 & 4 & 2 & 2 & \\
\hline Class 4 & Quad Cities 1 & 5 & 1 & 2 & 2 \\
\hline Class 4 & Quad Cities 2 & 5 & 1 & 2 & 2 \\
\hline
\end{tabular}




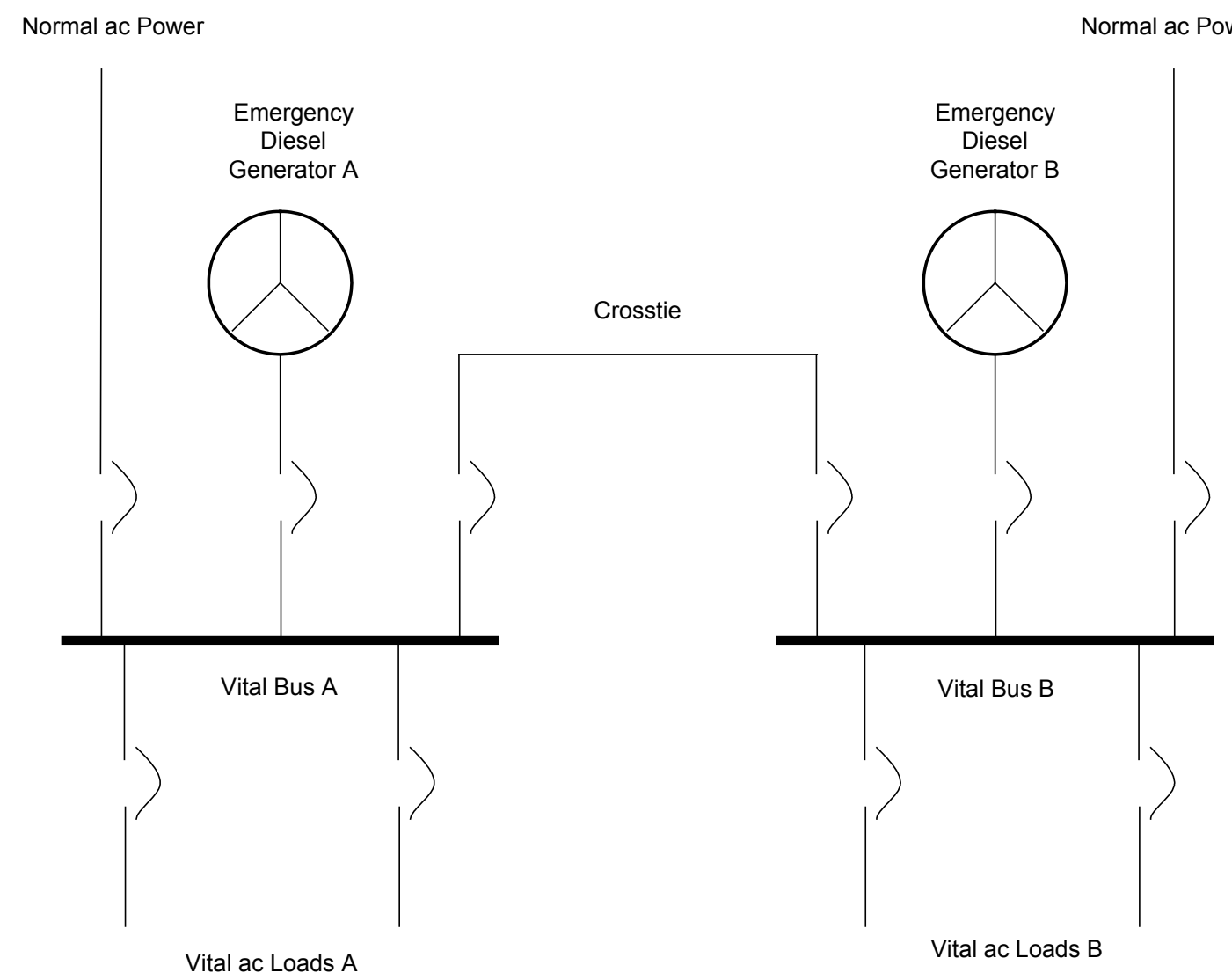

Figure 9. Simplified EPS system schematic. 
System Study

Emergency Power System
2014 Update December 2015 


\section{REFERENCES}

1. Nuclear Regulatory Commission, Component Reliability Data Sheets Update 2010, January 2012, http://nrcoe.inl.gov/resultsdb/publicdocs/AvgPerf/ComponentReliabilityDataSheets2010.pdf

2. S.A. Eide et al., Industry-Average Performance for Components and Initiating Events at U.S. Commercial Nuclear Power Plants, Nuclear Regulatory Commission, NUREG/CR-6928, February 2007. 